
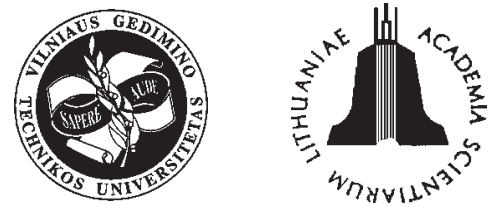

ISSN $1392-3730$

JOURNAL OF CIVIL ENGINEERING AND MANAGEMENT

http:/www.jcem.vgtu.lt

2005, Vol XI, No 4, 289-297

\title{
EXTENDED LINEAR PROGRAMMING IN MODELS OF LOCATION OF CONCRETE MIX PRODUCTION PLANTS
}

\author{
Edwin Koźniewski ${ }^{1}$, Zygmunt Orłowski ${ }^{2}$ \\ Institute of Civil Engineering, Biatystok University of Technology, ul. Wiejska 45E, 15-351 Biatystok, Poland. \\ E-mail:11edwikozn@pb.bialystok.pl,22zorl@pb.bialystok.pl
}

Received 03 June 2005; accepted 06 Oct 2005

\begin{abstract}
The paper discusses the location problem of production plants exemplified by concrete mix production plants ( ${ }^{\text {st }}$ model), taking into consideration the demand variability in time (II ${ }^{\text {nd }}$ model), and the analytical method of the localization of industrial plant with a considerable amount of transportation costs of concrete mix and concrete aggregate (III ${ }^{\text {rd }}$ model). Changes in demand for concrete mix in time $t$ lead to changes in plants' location. Assuming that there exist concrete mix production plants, one should make a simulation of demand for concrete mix which occurs at the time $t$. The presented models are the essential generalisation of the problem discussed in the earlier papers. The matrix of construction costs must be always defined as a four-dimensions vector (the set of four values): the production plant construction cost, the cost of plant's modernisation (which is the result of changing demand for concrete mix), the cost of liquidation (dismantling) of a production plant or the cost of moving of an existing production plant. Three new generalised notions concerning the classical linear programming (mixed programming, mixed programming with time and two-optimised conjugate linear system) have been introduced. The algorithms describing the above-mentioned models of location changes were suggested, and programmes solving the location problems were prepared in PASCAL.
\end{abstract}

Keywords: modelling of process, location problem, transportation method, concrete mix, linear programming, mixed programming, conjugate programming.

\section{Introduction}

The location problem of production plant is one of the classic optimization methods and is widely publicised. Let us just name such new works as Lu, Anson, Tang and Ying [1-4], Zayed and Halpin [5]. In [2] newly developed approaches for construction simulation have been used to model the one-plant-multisite ready mixed concrete (RMC) production system, validated by real-life operations data in Hong Kong. They used the HKCONSIM - a computer system for simulation modelling and analysis of Hong Kong's RMC production operations was developed in-house. The system is suitable for the resource provision planning and the production planning of a RMC plant, so as to meet given demands at a number of sites for concrete over a working day. In [5] a simulation is applied to concrete batching operations to analyse alternative solutions and resource management. Data are collected to define activity durations for the plant. A simulation model is constructed for the plant using the MicroCYCLONE simulation system. Based on sensitivity analysis, management tools are constructed to help the decision-maker. The problem of building location is discussed in Warszawski and Peer
[6]. Finally, the issue of auxiliary production plant location, which is the subject of the present paper, is discussed in numerous recent works, eg Warszawski [7, 8], Warszawski and Ishai [9], Celińska-Mysław and Kapliński [10], Kapliński [11], just to mention the most significant ones. Since concrete-mixing production plants are only temporary by nature (they must be located within a short distance from construction sites, where building works are carried out only at certain periods), there emerges a necessity of dynamic location. The models formulated and used in [12-14] and presented below are based on the classic location model related to the problem of linear and integer programming [15-21], combinatorial optimization [22], discrete optimization [23, 24] and combinatorial theory [25]. The papers [12-14] contain computational examples. In this paper three essential models, from mathematical point of view, are presented.

In the $\mathrm{I}^{\text {st }}$ model a problem of finding a conditional minimum of the linear function of $m \times n+m$ variables, where $m \times n$ of variables are continuous ones and the remaining $m$ are zero-one variables is considered. The constraints are linear inequalities. There is a global solution of the problem in the sense of general algorithm. 
The search for such a solution with the so-called method of decomposition has not brought an effective calculating method to Sysło $[23,26]$ yet. If we assume the values a sequence of zero-one variables, a classic transportation problem is obtained with zero-one variables. The solution of thus formulated problem can be found by two methods:

- Searching for the method directly solving the set task. It would be an interesting solution, but it is apparently very difficult (if possible at all). Provided the optimization method is skilfully found, the results are quickly obtained.

- Treating the set task as the total of numerous problems PL with variation number indexing. This, in turn, can be done in two ways: (a) by solving the task with zero-one variables and, subsequently, the transportation task (that procedure was used when algorithms of solutions in the respective models of the present paper were formed), or in the reverse order (b).

The procedure in 2(a) will be undoubtedly effective (however, not very spectacular, especially with a large number of zero-one variables), if while calculating the values of zero-one variables, all their possible arrangements are examined. That is where we have to face the problem of computer's work time. The models described in the paper, reflecting the technical and economic issues are associated with different solution algorithms. Certain variants require examining a bigger number of possibilities, others smaller. The mixed programming task, described in the $\mathrm{I}^{\text {st }}$ model - merges combinatory method and the method of transportation problem solving.

\section{It $^{\text {st }}$ model (mixed linear programming)}

As one may know, the transportation problem is an example of linear programming with continuous variables, and question of distribution is an example zero-one programming. The problem of location discussed in this paper is an example of mixed programming, and combines the two questions mentioned above. It is a task of linear programming where its variables are binary and continuous. Moreover, it is a combinatory problem.

\subsection{Mathematical formulation}

There are $m$ industrial plants, which produce goods for $n$ customers with demand for $d_{j}$ units, $j=1,2, \ldots, n$. The plant construction involves necessary costs for realisation the territorial investment $c_{i}\left(c_{i}=0\right)$ and its productivity $p_{i}\left(p_{i}=0\right)$. Unitary transportation cost of a unit of a product from a plant $i$ to a customer $j$ is $a_{i j}$. We want to select such a plant and its location so that the total cost is minimal and the demand $d_{j}$ is met. If $y_{i j}$ denotes the size of freight from the production plant $i$ to a customer $j$ and if $x_{i}$ denotes the choice or rejection of a production plant, the problem of location is as follows.

Data:

$m$ - the number of candidate sites for the plant location,

$n$ - the number of potential customers,

$d_{j}$ - the number of units required at destination $j, j=1$, $2, \ldots, n$,

$a_{i j}$ - the transportation cost per unit of a product from production plant $j$ to a customer $j$,

$c_{i}$ - the construction cost of the $i$-th production plant, $i=1,2, \ldots, m\left(c_{i} \geq 0\right)$,

$p_{i}$ - productivity of the $i$-th production plant, $i=1,2$, $\ldots, m,\left(p_{i}=0\right)$,

$y_{i j}-$ an amount transported from production plant $i$ to a customer $j$,

$x_{i}$ - a binary variable which denotes for $x_{i}=1$ the choice of $i$, while for $x_{i}=0$ the rejection of a production plant.

The solution of the location problem is based on finding the minimum of the function

$$
z=\sum_{i=1}^{m} \sum_{j=1}^{n} a_{i j} y_{i j}+\sum_{i=1}^{m} c_{i} x_{i}
$$

with the following constraints

$$
\begin{aligned}
& \sum_{i=1}^{m} y_{i j}=d_{j}, \quad j=1,2, \ldots, n, \\
& \sum_{j=1}^{n} y_{i j} \leq p_{i} x_{i}, \quad i=1,2, \ldots, m,
\end{aligned}
$$

where $y_{i j} \geq 0$ are continuous variables, while $x_{i}-$ binary variables.

It may occur that certain $x_{i}$ will equal zero. It means that some locations were not selected. In order to obtain a more general model, ie the one in which the number of plants is smaller or the same as that of possible site, one ought to assume that the number of production plants $z_{r}(r=1,2, \ldots, k)$ to locate equals $k$ and it is smaller or the same as $m$. In practice it means that we have any large number of locations and accordingly smaller number of plants. That assumption can be realised by assuming that certain $p_{i}$ equals zero and considering the permutations of the set $\left\{z_{1}, z_{2}, \ldots, z_{m}\right\}$ (where certain $z_{1}$ are fictions plants of production capacity which equals zero) or otherwise, which brings the same result, a set $\{1,2, \ldots, m\}$, but practically it is a set of $k$-element variations without $m$ - element set $\{1,2, \ldots, m\}$ repetitions, since the elements (production plants) $i$ in permutation of the value $p_{i}=0$ do not exist. Let us assume then that we own $k$ production plants $z_{r}(r=1,2, \ldots, k)$ of $q_{r}$ $(r=1,2, \ldots, k)$ production capacity, where $k-m$. A set of $V_{m}^{k}$ all $k$-element variation is defined without $\{1,2$, $\ldots, m\}$ set duplications. For a variation $\left(i_{1}, i_{2}, \ldots, i_{k}\right) p_{i}=q_{i}$ let us assume $i=i_{r}$ and $p_{i}=0$ for $i \notin\left\{i_{1}, i_{2}, \ldots, i_{k}\right.$. Since all the permutations are considered in the model, it does not matter how the set is arranged $\left\{i_{1}, i_{2}, \ldots, i_{k}\right\}$. 
In practice, as one can see in the following example, not decreasing the generality, we assume as $\left\{i_{1}, i_{2}, \ldots, i_{k}\right\}$ the set $\{1,2, \ldots, k\}$, ie we assume that the first $k$-elements of $p_{i}$ is different from 0 , while for other $m-k$ indexes $\{k+1, k+2, \ldots, m\} \quad p_{i}$ equals zero. We shall then obtain $\frac{m !}{(m-k) !}$ specimens of the model described above, however, in any case it will be a classic transportation task. In order to achieve an effective, possibly simple solution to the discussed model, we shall consider its three exemplifications.

\subsection{Problem solution}

The cost of construction $c_{i}$ of $i$-th plant, $i=1,2, \ldots$, $m\left(c_{i}=0\right)$ consists of two elements: costs $l_{j k}, k=1,2$, $\ldots, m_{i l}$, associated with land acquisition (purchase, leasing) and its development (fitting power mains, plumbing, telephone lines...), environmental costs, ...; $b_{i s}$ costs, $s=1,2, \ldots, m_{i b}$ which are associated with the construction and utilization of the building, ... (variant B). Therefore:

$$
c_{i}=\sum_{r=1}^{m_{i l}} l_{i r}+\sum_{s=1}^{m_{i b}} b_{i s}, \quad i=1,2, \ldots, m .
$$

Production capacity pi of the $i$-th production plant, $i=1,2, \ldots, m\left(p_{i}=0\right)$, may depend on the location (it may be appropriate only for that location - variant B), it may be independent of location (variant $C$ ) or it may be constant (variant A) the same as $p$.

Therefore the task has three forms:

Variant A. We assume that the located plants are typical, ie the cost of investment is identical to that of any other plant $\left(c_{i}=\right.$ const, $p_{i}=$ const, $\left.i=1,2, \ldots, m\right)$. The problem is to locate a few plants of certain (identical) production capacity and identical cost of construction. Considering that variant is interesting because of its realisation by means of a computer. In fact, the program operates over a relatively short period of time, which makes it possible to optimise the location of a greater number of industrial plants.

Variant B. The second assumption relies on a model, in which the location site is associated with the cost of construction (eg both land purchase and environmental issues seriously affect the costs of construction). However, the cost of investment and operating cost is entirely associated with the location. It means that the industrial plant $z_{r}$ can only be built on the site $k$. Vast majority of costs (significant value $l_{i r}, i=1,2, \ldots, m$, $r=1,2, \ldots, m_{i l}$ compared with $b_{i s}=$ const for $i=1,2$, $\left.\ldots, m ., \quad s=1,2, \ldots, m_{i b}\right)$ is associated with a location while $b_{i s}=$ const, $s=1,2, \ldots, m_{i b}$. That problem also has its economic solution by means of a computer because of a shortage of time. The above distinction, because of a computer algorithm, is not essential. In this case the algorithm does not actually differ from the one of the previous solution (variant A).

Variant C. At last the most general model where each industrial plant $z_{r}, r \in\{1,2, \ldots, m\}$ of certain investment costs and certain production capacity can be constructed on any site $i$. The cost of construction and its production capacity are independent of its location. The algorithm is not much more complicated while its realisation on a computer is distinctly longer. In practice it was calculated that 10 is a maximum number of locations and industrial plants.

The above distinction is very important from the technical, economic and ecological point of view. One should be aware of that when using a computer. All variants of the solution of the $\mathrm{I}^{\text {st }}$ model are presented in Table 1 .

\subsection{The description of solution algorithm}

Variant A is simple in such a way that the algorithm does not require permutations of variables standing for the industrial plants. It is limited to generating such binary digits, which when extended by the length $m$ have $k$ number of ones and $(m-k)$ zeros. Thus the solution of the transportation problem keep recurring as many times as there are $k$-element combinations of $m$-element set. The loop checking the values of the destination function of the transportation problem is realised $\left(\begin{array}{l}m \\ k\end{array}\right)$ times and not $\left(\begin{array}{l}m \\ k\end{array}\right) k !$ times. In case of bigger values of $k$ program's operation is dramatically shortened ( $k$ ! times).

Variant B differs from variant A only in the character of the initial data, concerning the cost of the plant's construction (values of $c_{i}$ ).

Variant $\mathrm{C}$ as the most general and the most universal is realised $k$ ! times longer - it is the time required to designate all the permutations for the respective combinations of location sites of the industrial plants.

There are $m$ location sites, $k$ industrial plants of production values $p_{i}, i=1,2 \ldots, k,\left(p_{i} \geq 0\right)$ of construction $\operatorname{cost} c_{i}, i=1,2 \ldots, k,\left(c_{i} \geq 0\right)$. Then in the transportation task we assume $p_{k+1}=p_{k+2}=\ldots=p_{m}=0$ and $c_{k+1}=c_{k+2}=\ldots=c_{m}=0$.

The other data ie $n, d_{j}, a_{i j}$ for $i=1,2, \ldots, m, j=1$, $2, \ldots, n$ remain invariance in all algorithms.

After thus modified matrix $p_{i}$ for $i=1,2, \ldots, m$ for each combination (variants $\mathrm{A}$ and $\mathrm{B}$ ) and any other variation (variant $\mathrm{C}$ ) we solve the transportation problem. If we assume that the set $K$ of combination (variants $\mathrm{A}$ and B) or the set $W$ of variation (variant C) has $w$ elements, then for each $t$-th combination (variation) $t=1,2, \ldots, w$ we solve the following task:

For the data:

$m$ - the number of industrial plants (location sites) we want to locate, 
Table 1. Variants of solution of the $\mathrm{I}^{\text {st }}$ model

\begin{tabular}{|c|c|c|c|}
\hline & Variant A & Variant B & Variant $\mathrm{C}$ \\
\hline 莺 & $\begin{array}{l}\underbrace{p, p, \ldots, p}_{k}, \underbrace{0,0, \ldots, 0}_{m-k} \\
\underbrace{p, p, \ldots, p}_{k}, \underbrace{0,0, \ldots, 0}_{m-k}\end{array}$ & $\begin{array}{l}p_{1}, p_{2}, \ldots, p_{k}, p_{k+1}, \ldots, p_{m} \\
c_{1}, c_{2}, \ldots, c_{k}, c_{k+1}, \ldots, c_{m}\end{array}$ & $\begin{array}{l}p_{1}, p_{2}, \ldots, p_{k}, \underbrace{0,0, \ldots, 0}_{m-k} \\
c_{1}, c_{2}, \ldots, c_{k}, \underbrace{0,0, \ldots, 0}_{m-k}\end{array}$ \\
\hline 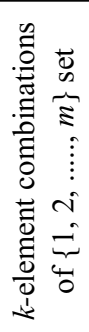 & $\begin{array}{l}\left\{i_{1}, i_{2}, \ldots, i_{k}\right\}, \\
\text { where } \\
i_{1}<i_{2}<\ldots<i_{k}, \\
\text { we assume: } \\
p_{i}:=p, c_{i}:=c \\
\text { for } i \in\left\{i_{1}, i_{2}, \ldots, i_{k}\right\}, \\
p_{i}:=0, c_{i}:=0 \\
\text { for } i \notin\left\{i_{1}, i_{2}, \ldots, i_{k}\right\}\end{array}$ & $\begin{array}{l}\left\{i_{1}, i_{2}, \ldots, i_{k}\right\}, \\
\text { where } \\
i_{1}<i_{2}<\ldots<i_{k}, \\
\text { we assume: } \\
p_{i}:=0, c_{i}:=0 \\
\text { for } i \notin\left\{i_{1}, i_{2}, \ldots, i_{k}\right\}, \\
\text { the others are the same }\end{array}$ & $\begin{array}{l}\left\{i_{1}, i_{2}, \ldots, i_{k}\right\} \\
\text { where } \\
i_{1}<i_{2}<\ldots<i_{k} .\end{array}$ \\
\hline . & - & - & $\begin{array}{l}\text { We assume } \\
q_{i_{j}}:=p_{j}, e_{i_{j}}:=c_{j}, p_{i}:=0, c_{i}:=0 \\
\text { for } i \notin\left\{i_{1}, i_{2}, \ldots, i_{k}\right\} . \\
\text { We create permutation } \\
i_{1}^{\prime}{ }_{1}, i_{2}, \ldots, i_{k}{ }_{k} \text { of the set }\left\{i_{1}, i_{2}, \ldots, i_{k}\right\}, \\
\text { and we assume } \\
p_{i_{j}}:=q_{i^{\prime} j}, c_{i_{j}}:=e_{i^{\prime} j} \\
\text { and } p_{i}:=0, c_{i}:=0 \text { for } i \notin\left\{i_{1}, i_{2}, \ldots, i_{k}\right\}\end{array}$ \\
\hline
\end{tabular}

$n-$ the number of potential customers,

$d_{j}$ - the number of units of the product in demand from the $j$-th customer, $j=1,2, \ldots, n$,

$a_{i j}-\mathrm{a}$ unitary cost of transport of a unit of a product from the industrial plant $z$ to a customer $j$,

$p_{i}$ - the productivity of the $i$-th industrial plant, $i=1,2$, $\ldots, m, \quad\left(p_{i} \geq 0\right)$,

$y_{i j}$ - a size of the freight from the industrial plant $i$ to a customer $j$,

find the function minimum

$$
z_{t}=\sum_{i=1}^{m} \sum_{j=1}^{n} a_{i j} y_{i j}
$$

with these constraints

$$
\begin{aligned}
& \sum_{i=1}^{m} y_{i j}=d_{j}, \quad j=1,2, \ldots, n, \\
& \sum_{j=1}^{n} y_{i j} \leq p_{i}, \quad i=1,2, \ldots, m .
\end{aligned}
$$

For the found function minimum $z$ we find the value

$$
z_{t}^{\prime}=\sum_{i=1}^{m} c_{i} x_{i},
$$

where $x_{1}, x_{2}, \ldots, x_{m}$ is a binary digit defining the combination $\left\{i_{1}, i_{2}, \ldots, i_{k}\right\}$ ie $x_{i}:=1$, for $i \in\left\{i_{1}, i_{2}, \ldots, i_{k}\right\}$ and $x_{i}:=0$, for $i \notin\left\{i_{1}, i_{2}, \ldots, i_{k}\right\}$. form:

The required optimum solution is the one in the

$$
\min _{t=1,2, \ldots, w}\left(z_{t}+z_{t}^{\prime}\right)
$$

\section{II ${ }^{\text {nd }}$ model (Production plant location with func- tion of time)}

In $\mathrm{I}^{\mathrm{st}}$ model the solution involved the situation static in time. Such a solution of the question with a complete algorithm, effective program and examples is not found in other papers although they are fairly numerous. Warszawski in [7] discusses the question of location, offering an interesting mathematical model, however, he does not suggest an effective algorithm of the question solution. Moreover, in none of the above-mentioned papers offers a comprehensive cost analysis associated with the construction, modernisation or liquidation of the plant.

Since the concrete-production plants are temporary by nature, there appears a need of a dynamic location. The changes concerning the demand for concrete mix force the changes in plants' location. It may happen periodically or there may be a possibility of predicting the demand for concrete for many years ahead. The changes of location in time force multi-variant location changes. The above issues are the subject of the II $^{\text {nd }}$ model.

\subsection{Mathematical formulation}

Let's assume that we have $m$ concrete mix plants, where at any moment of time $t(t \in T)$ concrete mix is produced for $n$ customers at the demand of $d_{j}(t)$ units, $j=1,2, \ldots, n$. After a time $\Delta t$, the demand for the quantity of concrete mix will be a subject to change; it may increase or decrease. The company which owns a plant faces the option of constructing new plant, modernisation, moving it elsewhere or liquidation. All the above-men- 
tioned decisions involve costs, which are necessary to carry out the investment $c_{i}(t)\left(c_{i}(t) \geq 0\right)$ and provide production capacity $p_{i}(t)\left(p_{i}(t) \geq 0\right)$. The cost of transporting a unit of a commodity from a plant $i$ to the customer $j$ amounts to $a_{i j}(t)$. We want to select such a plant and its location so that its total cost is minimal and demand $d_{j}(t)$ satisfied. If we assume that $y_{i j}(t)$ is the capacity of the load from a plant $i$ to a customer $j$ and if $x_{i}(t)$ stands for the selection or rejection of a plant, the question of location can be described as follows:

As far as a mathematical formulation of the problem is concerned, it is necessary to denote the parameters of the system and the decision variables.

The data:

$m \quad-$ the number of candidate sites for the plant location,

$m, m_{0}-$ the number of industrial plants,

$n$ - the number of potential customers,

$d_{j}(t)$ - the number of units of concrete mix $\left[\mathrm{m}^{3}\right]$ required at a destination, $j=1,2, \ldots, n, t \in T$,

$a_{i j}(t)$ - the cost $\left[P L N / m^{3}\right]$ of transport per unit of a product from a production plant $i$ to a customer

$$
j, t \in T \text {, }
$$

$c_{i}(t)$ - the cost of construction [PLN] of the $i$-th production plant, $i=1,2, \ldots, m, \quad\left(c_{i}(t) \geq 0\right)$,

$t \in T, p_{i}(t)$ - productivity per year $\left[\mathrm{m}^{3}\right]$ of the $i$-th production plant, $t \in T$.

Its decision variables are as follows:

$y_{i j}(t)$ - an amount of a product $\left[\mathrm{m}^{3}\right]$ transported from a production plant $i$ to a customer $j, t \in T$,

$x_{i}(t)$ - a binary variable which denotes the choice of $i$ for $x_{i}(t)=1$, while for $x_{i}(t)=0$ - the rejection of a production plant, The solution of the location problem is based on finding the minimum of the function

$$
z(t)=\sum_{i=1}^{m} \sum_{j=1}^{n} a_{i j} y_{i j}(t)+\sum c_{i}(t) x_{i}(t)
$$

with the following constraints:

$$
\begin{gathered}
\sum_{i=1}^{m} y_{i j}(t)=d_{j}(t), \quad j=1,2, \ldots, n, t \in T, \\
\sum_{j=1}^{n} y_{i j}(t) \leq p_{i}(t) x_{i}(t), \quad i=1,2, \ldots, m, t \in T
\end{gathered}
$$

where $y_{i j}(t) \geq 0$ are continuous variables, while $x_{i}(t)-$ are binary variables.

For the salve of clarity, the numbers $m$ and $m_{0}$ will be treated as identical, assuming that there are $m-m_{0}$ fictional production plants, for which $p_{i}(t)=0, \quad i=1$, $2, \ldots, m-m_{0}$.

The function of purpose (11) denotes the total of costs associated with the transport of concrete mix from a production plant $i$ to a customer $j$ in a period of time $t$ and the costs associated with the construction, modernisation or moving of a plant (in a discussed pe- riod of time $t$ ). The equations (12) define the constraints that the capacity of suggested production plants is higher (equal) than the demand of customers for concrete mix (in a period of time $t$ ), ie concrete mix will be delivered to all the customers (in a period of time $t$ ). With a fixed $t$ a similar model is obtained to that (or those) described in the $\mathrm{I}^{\text {st }}$ model. Thus, we are not going to describe that (stationary) model again, the more so that at the present assumptions the solution of the problem with fixed $t$ depends upon the solution in a previous period $t-\Delta t$, where $\Delta t(\Delta t \geq 0)$ is a period of time (or its multiple) between the subsequent decisions concerning the production plant location. Practically, it is assumed that boundary conditions (and all data generally) will change in time in a discreet way. The time range $T$ is divided into time sections $\Delta t_{u}=<t_{u-1}, t_{u}>$, for $u=1,2, \ldots, o$, so that $\cup_{u=1,2, \ldots, o}<t_{u-1}, t_{u}=T$. The data described above have the form of a matrix with one more indicator $u, u=1,2$, $\ldots, o$. About the quantities $a_{i j}(t)$ the matrix has the 3-dimensional form $a_{i j}\left(t_{u}\right)$, with dimensions of $m \times n \times o$, $i=1,2, \ldots, m, j=1,2, \ldots, n, u=1,2, \ldots, o$. The problem is solved at the moment $t_{u}$ with the use of one of the models described in the $\mathrm{I}^{\text {st }}$ model. As a result, we obtain an optimal solution in the form of arrangement variation $\pi_{u}(i), u=1,2, \ldots, o$ with the minimum value of $z\left(t_{u}\right)=\min _{r=1,2, \ldots, w}\left(z_{r}\left(t_{u}\right)+z_{r}^{\prime}\left(t_{u}\right)\right)$, where $w$ is the number of variations $\left(z_{r}\left(t_{u}\right)\right.$ is the value of the function of purpose in a classical PL for the $r$-th variation, while $z_{r}^{\prime}\left(t_{u}\right)=\sum_{i=1}^{m} c_{i}(t) x_{i}(t)$ is a global value of investment on the construction (modernisation) of production plants.

\subsection{General description of algorithm solution}

The main idea of solving the problem is based on multiple use of the algorithm described in $\mathrm{I}^{\text {st }}$ model with the proper choice of values $c_{i}\left(t_{u}\right)$ of the data (10). Temporarily, in order to simplify the form, the following assumptions are made: $t_{u}$ shall be identified with $u$ and it will denote $a_{u}(i, j)$ instead of $a_{i j}\left(t_{u}\right), c_{u}(i)$ instead of $c_{i}\left(t_{u}\right)$ etc. In the discussed model the cost of construction of a production plant can have varied character. It can be the construction of a new production plant, development of the existing plant, the change of location of already existing plant or liquidation of the production plant. Hence, the matrix of construction costs must be on all occasions defined as a four-dimension vector (the set of four values): $c_{u}(i)=\left(\alpha_{u}(i), \beta_{u}(i), \gamma_{u}(i), \delta_{u}(i)\right)$, where $i=1$, $2, \ldots, m, u=1,2, \ldots, o$ and the co-ordinates of the vector signify respectively $\alpha_{u}(i)-$ the production plant construction cost, $\beta_{u}(i)$ - the cost of plant's modernisation (connected with changing demand for concrete mix, $\gamma_{u}(i)$ - the cost of liquidation (dismantling) of a production plant, $\delta_{u}(i)$ - the cost of change in location of an existing production plant. 
Let $\pi$ denote any variation of production plant location layout, $\pi_{u}$ denotes variation of production plant location layout at the time $u, \pi_{u}(i)$ - the value of variations for the $i$-th site at the time $u$, or a production plant established in on available site $i$. Then, the following cases may be distinguished:

$$
\begin{aligned}
& \text { if } \pi_{u}(i)=\pi_{u+1}(i) \text { and } p_{u}(i) \geq p_{u+1}(i) \text {, } \\
& \text { then we assume } c_{u+1}(i):=0 \text {, }
\end{aligned}
$$

if $\pi_{u}(i) \neq \pi_{u+1}(i)$ and $\pi_{u}(i) \neq 0$ and $\pi_{u+1}(i)=\pi_{u}(j)$ for some $j \neq i$, then we assume $c_{u+1}(i):=\delta_{u+1}\left(\pi_{u+1}(i)\right)$,

if $\pi_{u}(i) \neq \pi_{u+1}(i)$ and $\pi_{u+1}(i)=0$ and $\pi_{u+1}(j) \neq \pi_{u}(i)$ for every $j \neq i$,

then we assume $c_{u+1}(i):=\gamma_{u+1}\left(\pi_{u}(i)\right)$.

The above cases are illustrated in Table 2.

Table 2. The illustration of variations of production plant location

\begin{tabular}{c|c|c|c|c|c|c|c|c}
\hline & $\pi(1)$ & $\pi(2)$ & $\pi(3)$ & $\pi(4)$ & $\pi(5)$ & $\pi(6)$ & $\pi(7)$ & $\pi(8)$ \\
\hline$\pi_{u}$ & $\mathbf{1}$ & 0 & $\mathbf{4}$ & $\mathbf{2}$ & $\mathbf{3}$ & 0 & 0 & $\mathbf{5}$ \\
\hline$\pi_{u+1}$ & 0 & $\mathbf{5}$ & $\mathbf{3}$ & $\mathbf{2}$ & $\mathbf{4}$ & 0 & $\mathbf{6}$ & $\mathbf{0}$ \\
\hline & $(14 \mathrm{e})$ & $(14 \mathrm{~d})$ & $\begin{array}{c}(14 \mathrm{~d}) \\
\text { or } \\
(14 \mathrm{~b})\end{array}$ & $(14 \mathrm{a})$ & $\begin{array}{c}(14 \mathrm{~d}) \\
\text { or } \\
(14 \mathrm{~b})\end{array}$ & $(14 \mathrm{a})$ & $(14 \mathrm{c})$ & $(14 \mathrm{~d})$ \\
\hline
\end{tabular}

First, the initial stage is carried out:

(the initial stage): $c_{u}(i):=\alpha_{u}(i), \quad i=1,2, \ldots, m, u=0$.

Each phase of transition from the state at the time $u$ to the state at the time $u+1$ takes place in three stages. At the initial moment of the algorithm (at the start) we have: for:

Stage 1 is based on solving the problem of location $c_{u+1}(i):=0$ in the case of $p_{u}(i) \geq p_{u+1}(i)$, $c_{u+1}(i):=\beta_{u+1}\left(\pi_{u+1}(i)\right)$ in the case of $p_{u}(i)<p_{u+1}(i)$ for the location at the time $u$ (variation $\pi$ ).

In stage 2 we solve the problem assuming the principle (14 a-e) and we select the best solution of those obtained in stage 1 and stage 2. Notice that stage 2 is needed (has an essential influence on the problem solution) when the modernisation of existing production plants is unprofitable.

The algorithm suggested in the paper is based on multiple application of the program used in the $\mathrm{I}^{\text {st }}$ model, which can dynamically find the optimum location, supplemented with a stationary sub-programme which calculates the total cost of transport in the previous stages.

\subsection{The cost of production plant construction}

Construction cost $c_{i}\left(t_{u}\right), i=1,2, \ldots, m, \quad\left(c_{i}\left(t_{u}\right) \geq 0\right)$ of the $i$-th production plant, expressed with four values in our model, consists of, as in [4] two components: costs $l_{i k}\left(t_{u}\right), k=1,2, \ldots, m_{i l}$, associated with land acquisition (purchase, rent) and its development (sewage, electricity supply, telephone installation, etc), ecological costs etc; costs $b_{i s}\left(t_{u}\right), s=1,2, \ldots, m_{i b}$ connected with the construction and exploitation of the production plant etc. Because of diversification of variants resulting from the type of investment the above decomposition of costs refers only to the construction of a new production plant. The other cases as well as a detailed analysis of the above costs is omitted here considering the character of the paper.

Thus

$$
c_{i}\left(t_{u}\right) \sum_{r=1}^{m_{i l}} l_{i r}\left(t_{u}\right)+\sum_{s=1}^{m_{i b}} l_{i s}\left(t_{u}\right), i=1,2, \ldots, m .
$$

As mentioned above, the cost $c_{i}\left(t_{u}\right)$ is perceived as a four-dimension vector $c_{u}(i)=\left(\alpha_{u}(i), \beta_{u}(i), \gamma_{u}(i), \delta_{u}(i)\right)$, in which $i=1,2, \ldots, m, u=1,2, \ldots, o$, because of the assumed stationariness in respect to time in the model, indices were written in a different way. Leaving out the question of time, the vector $c_{i}$ has the form of $\left(\alpha_{i}, \beta_{i}\right.$, $\left.\gamma_{i}, \delta_{i}\right)$.

\section{III ${ }^{\text {rd }}$ model (two-optimised linear conjugate system)}

In this model we optimise the objective function depend on

- a location of potential customers of concrete mix and

- a location of open casts of concrete aggregate.

We obtain an example of two tasks of linear programming associated with each other. Such a composed task is called by the authors two-optimised linear conjugate system.

\subsection{Mathematical formulation}

Let us assume we have $m$ concrete mix plants, where at any time moment concrete mix is produced for $n$ customers. For the production of concrete mix we use $v$ kinds of concrete aggregates originating from $l$ open casts (sources). The problem of location can be described as follows.

Data:

$m, m_{0}$ - the numbers: $m$ - of candidate sites for the plant location, $m_{0}$ - of industrial plants,

$n-$ the number of potential customers,

$d_{j}(t)$ - the number of units of concrete mix $\left[\mathrm{m}^{3}\right]$ required at a destination, $j=1,2, \ldots, n, t \in T$,

$a_{i j}(t)$ - the cost $\left[P L N / m^{3}\right]$ of transport per unit of a product from a production plant $i$ to a customer $j, t \in T$, 
$c_{i}(t)$ - the cost of construction $[P L N]$ of the $i$-th production plant, $i=1,2, \ldots, m, \quad\left(c_{i}(t) \geq 0\right), t \in T$,

$p^{\prime}(t)$ - the productivity (per year) $\left[\mathrm{m}^{3}\right]$ of the $i$-th production plant, $i=1,2, \ldots, m,\left(p_{i}^{\prime}(t) \geq 0\right), t \in T$,

$p_{i}(t)$ - the productivity (per year) $\left[\mathrm{m}^{3}\right]$ of the $i$-th production plant, after using the correction coefficient of the production power, $i=1,2, \ldots, m$, $\left(p_{i}(t) \geq 0\right), t \in T$,

$y_{i j}(t) \quad-$ an amount of a product $\left[\mathrm{m}^{3}\right]$ transported from a production plant $i$ to a customer $j, t \in T$,

$x_{i}(t) \quad$ - a binary variable which denotes the choice of $i$ for $x_{i}(t)=1$, while for $x_{i}(t)=0$ - the rejection of a production plant, $t \in T$,

$l \quad-$ the number of open casts (sources of concrete aggregate),

$v \quad-$ the number of kinds of concrete aggregate used to the production of concrete mix,

$e_{k}(t)$ - the number of units of concrete aggregate $\left[\mathrm{m}^{3}\right]$ in open cast $k, k=1,2, \ldots, l, t \in T$,

$b_{k i s}(t)$ - the cost $\left[P L N / m^{3}\right]$ of transport of units of concrete aggregate of kind $s$ from an open cast $k$ to a production plant $i, k=1,2, \ldots, l, i=1,2$, $\ldots, m, s=1,2, \ldots, v, t \in T$,

$w_{k i s}(t)-$ an amount of a product of concrete aggregate $\left[\mathrm{m}^{3}\right]$ of kind $s$ transported from an open cast $k$ to a production plant $i, k=1,2, \ldots, l, i=1,2$, $\ldots, m, s=1,2, \ldots, n v, t \in T$,

$\lambda_{s}-$ the coefficient of a share of kind of concrete aggregate $s$ in concrete mix, $s=1,2, \ldots, v$, $\lambda_{1}+\lambda_{2}+\ldots+\lambda_{v}=100[\%]$

$\mu_{i} \quad-$ the coefficient of a utilization of the production power of a production plant $i$ in relation to a kind $s$ of the concrete mix, $i=1,2, \ldots, m$.

The solution of the location problem is based on finding the minimum of the function

$$
z(t)=m b(t)+k r(t)+b u(t)
$$

where:

$m b(t)$ - the total cost of the transport of a concrete mix [PLN],

$k r(t) \quad-$ the total cost of the transport of a concrete aggregate $[P L N]$,

$b u(t)$ - the production plant construction cost $[P L N]$,

and $y_{i j}, w_{k i s}(t)\left(y_{i j} \geq 0, w_{k i s}(t) \geq 0\right)$ are continuous variables, while $x_{i}$ - are binary variables.

The way of solving the problem is based on use the algorithm described as follows. Similarly as in II $^{\text {nd }}$ model, for every $t$ we generate all values of the coordinate vector $x_{i}(t)$ and we obtain the system numbers for each we solve the linear program (the minimum of the function $m b(t))$

$$
m b(t)=\sum_{i=1}^{m} \sum_{j=1}^{n} a_{i j}(t) y_{i j}(t)
$$

with the following constraints:

$$
\begin{gathered}
\sum_{i=1}^{m} y_{i j}(t)=d_{j}(t), \quad j=1,2, \ldots, n, t \in T, \\
\sum_{j=1}^{n} y_{i j}(t) \leq p_{i}(t) x_{i}(t), \quad i=1,2, \ldots, m, t \in T,
\end{gathered}
$$

where $y_{i j}(t) \geq 0$ are continuous variables, while $x_{i}(t)-$ are binary variables and $p_{i}=\mu_{i} p_{i}^{\prime}$ for $i=1,2, \ldots, m$ (cf. [11]).

We obtain the solution $y_{i j}^{0}(t), x_{i}^{0}(t)$. Next, we compute the values $p_{i}{ }^{0}(t)$ according to the equality

$$
p_{i}^{0}(t)=\sum_{j=1}^{n} y_{i j}^{0}(t)
$$

We compute the value of the function determining the cost of the construction of a production plant

$$
b u(t)=\sum_{i=1}^{m} c_{i}(t) x_{i}^{0}(t)
$$

Next we find the solution of the second linear program (the minimum of the function $k r(t)=\sum_{i=1}^{v} k r_{s}$ ) by mean the solving of $v$ component linear programs $s$ for $s=1,2, \ldots, v$,

$$
k r_{s}(t)=\sum_{k=1}^{l} \sum_{i=1}^{m} b_{k i s}(t) w_{k i s}(t)
$$

with the constraints:

$$
\begin{gathered}
\sum_{k=1}^{l} w_{k i s}(t)=\lambda_{s} p_{i}^{0}(t), \quad i=1,2, \ldots, m, t \in T, \\
\sum_{i=1}^{m} w_{k i s} \leq e_{k s}(t), \quad k=1,2, \ldots, l, t \in T .
\end{gathered}
$$

At the end the minimum of the function $z(t)(z(t)=$ $m b(t)+k r(t)+b u(t))$ we find by considering all variations which determine the systems of variables $x_{i}(t)$.

The considered above problem can be fomulated as one task LP. It suffices to substitute (20) into (23). Then we obtain the following model of the mixed linear programming: Find the minimum of the function (16) with the constraints (18), (19), (23), (24) (naturally with the modified notation). However, such a problem is not soluble by means of transportation method. There is a LP problem with the matrix $\mathbf{A}_{(m(n+l+1)) \times((m(l+1)+(m+1) v+n))}$ soluble $2^{m} v$ times instead of $2^{m} v$ double transhipment tasks with suitable $m \times n, m \times l$ dimensions. The second algorithm is most advantageous than the first one.

\section{Conclusions}

The three presented models of localisation make it possible to solve the problems of location of concrete mix production plants of different size and different organisational and environmental conditions. 
Model I refers to localisation of the concrete mix production plants where there is considerable influence of fixed costs on plant functioning costs. This model of localisation finds its application in small areas as well as in areas of medium size, where concrete mix production plants are characterised as constant objects.

Model II takes into consideration predicted changes in demand for concrete mix in time on a given territory. It means that the demand and the territory attended to will be different in different periods of time. Moreover, the model takes into account relocation, modernisation or liquidation (liquidation costs) of a production plant. The model is applied in the planning of localisation of concrete mix production plants (mobile concrete-mixing plants, among others) in big cities and on large urbanised territories.

Model III considers the case here the functioning of concrete mix production plants is influenced not only by the factors mentioned in the previous models (such as, among others, connections between concrete mix production plants and the building sites which consume the concrete) but also by the environment, ie suppliers. In this regard, the location problem is solved here by optimisation of the objective function dependent on the location of points receiving the concrete mix, the demand, the places where raw materials are obtained and the amount of concrete mix production. The so-called two-optimised conjugate linear system is obtained. This model is applied in large city agglomerations, which do not have sources of raw materials in close neighbourhood or in smaller areas, which are considerably remote from the sources of concrete aggregate.

The presented algorithms of models solving enable a multidirectional analysis of location problems, which is also proved by the numerical examples $([12-14])$. It is possible to carry out simulation of different hypothetical economic and social situations, such as: changes of transport charges (changes of fuel costs), changes in the cycle of object realisation, social-political changes, which may result in increase in the demand for concrete mix (eg introduction of tax preferences for economic objects and natural persons who realize building investments), etc. Versatility of the models allows the designer to decide how to react to the changing surroundings, where to look for improvements in the activity of a firm or in logistics, as well as to solve material, equipment and organisational problems.

\section{Acknowledgement}

This work has been supported by the Białystok University of Technology through the research grant No S/IIB/5/02, S/IIB/1/05.

\section{References}

1. Tang, S. L.; Ahmad, I. U.; Ahmed, S. M. and Lu, M. Quantitative Techniques for Decision Making in Construction. Hong Kong University Press, 2004. 226 p.

2. Lu, M.; Anson, M.; Tang, S. L. and Ying, Y. C. HKCONSIM: A Practical Simulation Solution to Planning Concrete Plant Operations in Hong Kong. Journal of Construction Engineering and Management, ASCE, Vol 129, Issue 5, Sept/Oct 2003, p. 547-554.

3. Ying, K. C.; Tang, S. L.; Anson, M. and Lu, M. Optimization of Ready Mixed Concrete Plant Operations Using Simulation Techniques. In: Proc. of $1^{\text {st }}$ intern conference on construction in the 21 st century: Challenges and opportunities in management and technology, Miami, USA, April 2002, p. 647-653.

4. Ying, K. C.; Tang, S. L. and Anson, M. Measurement of the Performance of Ready Mixed Concreting Resources as Data for System Simulation. Construction Management and Economics, Vol 20, No 3, 2002, p. 237-250.

5. Zayed, T. M. and Halpin, D. Simulation of Concrete Batch Plant Production. Journal of Construction Engineering and Management, Vol 127, Issue 2, March/Apr 2001, p. 132141.

6. Warszawski, A. and Peer, S. Optimized Location of Facilities on Building Site. Operations Research Quaterly, Vol 24, No 1, 1973, p. 24-29.

7. Warszawski, A. Industralized and Automated Building Systems. Taylorr \& Francis Books Ltd., 1999. 480 p.

8. Warszawski, A. Production Planning in Prefabrication Plant. Building and Environment, Vol 19, Issue 2, 1984, p. 139147.

9. Warszawski, A. and Ishai, E. Long Range Planning of Prefabrication Industry in a National Economy. Building and Environment, Vol 17, Issue 1, 1982, p. 47-54.

10. Celińska-Mysław, M. and Kapliński, O. The Application of the LINDO Program in Solving Location Problems for Concrete Mix Production Plants. Computer Methods in Civil Engineering (Metody Komputerowe w Inżynierii Lądowej), No 3, 1997, p. 65-77 (in Polish).

11. Kapliński, O. Modelling of Construction Processes. A Managerial Approach. IPPT PAN, Warsaw, 1997. 175 p.

12. Koźniewski, E. and Orłowski, Z. Parameters Influence on Production Plants Location. Engineering and Building (Inżynieria i Budownictwo), No 8, 2001, p. $462-464$ (in Polish).

13. Koźniewski, E. and Orłowski, Z. Auxiliary Production Plant Location in Function of Time. Archives of Civil Engineering, Vol 46, No 3, 2000, p. 451-467.

14. Koźniewski, E. and Orłowski, Z. Mixed Programming in Localization Models. Computer methods in civil engineering (Metody Komputerowe w Inżynierii Lądowej), No 3, 1997, p. 51-53 (in Polish).

15. Vanderbei, R. J. Linear Programming: Foundations and Extensions. $2^{\text {nd }}$ ed., Kluwer Academic Publishers, 2001. $472 \mathrm{p}$.

16. Anderson, E. D. and Anderson, K. D. Presolving in Linear Programming. Mathematical Programming, Vol 71, No 2, 1995, p. 221-245. 
17. Hansen, P.; Jaumard, B. and Mathod, V. Constrained Nonlinear 0-1 Programming. INFORMS Journal on Computing, Vol 5, No 2, 1993, p. 97-119.

18. Barnhart, C.; Johnson, E.; Nemhauser, G.; Sigismondi, G. and Vance, P. Formulating a Mixed Integer Programming Problem to Improve Solvability. Operations Research, Vol 41, No 6, Nov/Dec, 1993, p. 1013-1019.

19. Nering, E. D. and Tucker, A. W. Linear Programs and Related Problems. Academic Press, 1993. 584 p.

20. van Roy, T. J. and Wolsey, L. A. Solving Mixed Integer Programming Problems using Automatic Reformulation. Operations Research, Vol 35, No 1, 1987, p. 45-57.

21. Benders, J. F. Partitioning Procedures for Solving MixedVariables Programming Problems. Numerical Mathematics (Numerische Mathematik), Vol 4, No 2, 1962, p. 238 252.
22. Barahona, M.; Grötschel, M.; Jünger, M., G. and Reinelt, G. An Application of Combinatorial Optimization to Statistical Physics and Circuit Layout Design. Operations Research, Vol 36, No 3, 1988, p. 493-513.

23. Sysło, M. M.; Deo, N. and Kowalik, J. S. Discrete Optimization Algorithms with Pascal Programs (Algorytmy optymalizacji dyskretnej: z programami w języku Pascal). Wydawnictwa Naukowo-Techniczne, Warszawa, 1999. 444 p. (in Polish).

24. Roos, K.; Terlaky, T. and Vial, J.-Ph. Theory and Algorithms for Linear Optimization: An Interior Point Approach. John Wiley \& Sons, Chichester, 1997. 508 p.

25. Lipski, W. Combinatorics for Programmers (Kombinatoryka dla programistów). Wydawnictwa Naukowo-Techniczne, Warszaw, 2004. 274 p. (in Polish).

26. Lau, H. T. A Numerical Library in $\mathrm{C}$ for Scientists and Engineers. CRC Press, 1994. 795 p.

\section{IŠPLĖSTINIS BETONO GAMYKLŲ IŠDĖSTYMO TIESINIO PROGRAMAVIMO MODELIS}

\section{E. Koźniewski, Z. Orlowski}

\section{Santrauka}

Aptariama gamyklų išdèstymo problema iliustruota betono gamyklų pavyzdžiu. I modelyje nagrinėjamas betono gamyklos išdėstymas nepriklausomai nuo betono poreikio kitimo laikui bėgant. II modelyje i̇vertinamas betono poreikio kitimas laikui bėgant. III analiziniame pramonès gamyklų išdėstymo modelyje ivvertintos betono mišinio bei užpildo transportavimo išlaidos. Kintant betono poreikiui laikui bègant, kinta ir gamyklų išdèstymas. Esamoms betono gamykloms turi būti atliktas betono mišinio poreikio kitimo laikui bėgant modeliavimas. Pateikti modeliai apibendrina ankstesniuose straipsniuose suformuluotas esmines problemas. Statybos išlaidų matrica turi būti sudaryta kaip keturių dimensijų vektorius (keturiu reikšmių aibė): gamyklos statybos išlaidos, gamyklų modernizavimo išlaidos, kurias lemia betono poreikio kitimas, gamyklos likvidavimo išlaidos arba esamos gamyklos perkẻlimo išlaidos. Pateiktos trys naujos apibendrintos metodikos, susijusios su klasikiniu tiesiniu programavimu (mišrusis programavimas, mišrusis programavimas laikui bėgant ir pagal du požymius optimizuota jungtinè tiesinè sistema). Pasiūlyti išdèstymo modelių aprašymo algoritmai, kurių sprendimams parengtos kompiuterinès programos PASCAL programavimo kalba.

Raktažodžiai: proceso modeliavimas, išdėstymo problema, transportavimo metodas, betono mišinys, tiesinis programavimas, mišrusis programavimas, jungtinis programavimas.

Edwin KOŹNIEWSKI, PhD. Assistant Professor at the Institute of Civil Engineering, Engineering Graphics \& Computer Methods Division. Białystok University of Technology, Białystok, Poland. Member of International Society for Geometry and Graphics. His research interests are: descriptive and projective geometry, engineering and computer aided design graphics, mathematical methods in building.

Zygmunt ORLOWSKI, PhD. Assistant Professor in the Dept of Construction Engineering and Management, Institute of Civil Engineering, Białystok University of Technology, Białystok, Poland. Member of European Association of Product and Process Modelling (EAPPM). His research interests include mathematical methods in building process technology in civil engineering, particularly monolithic works. 